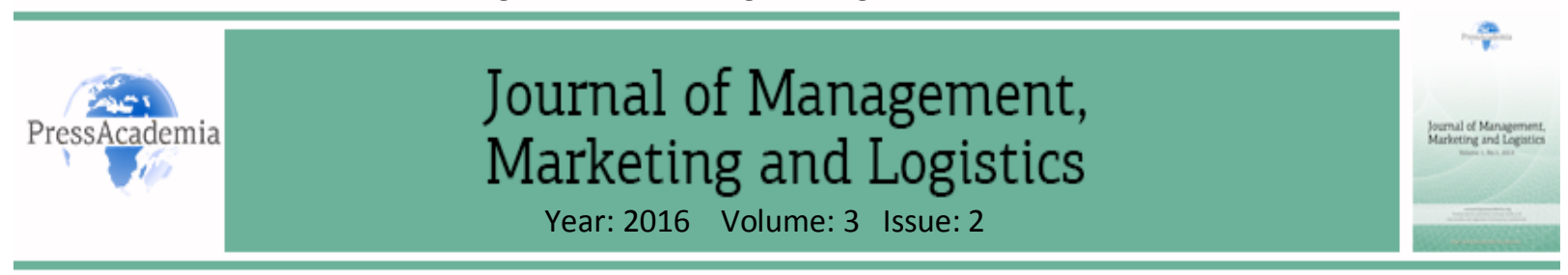

\title{
PRO-ENVIRONMENTAL CONSUMPTION: IS IT REALLY ALL ABOUT THE ENVIRONMENT?
}

\section{DOI: 10.17261/Pressacademia.2016219940}

\author{
Inci Dursun', Ebru Tumer Kabadayi², Cansu Gokmen Koksal ${ }^{3}$, Ahmet Tugrul Tuger ${ }^{4}$ \\ ${ }^{1}$ Yalova University. inci.dursun@yalova.edu.tr \\ ${ }^{2}$ Gebze Technical University. tumer@gtu.edu.tr \\ ${ }^{3}$ Gebze Technical University. ckoksal@gtu.edu.tr \\ ${ }^{4}$ Gebze Technical University. atuger@gtu.edu.tr
}

\begin{abstract}
The purpose of the current study is to investigate the relative impacts of consumers' concerns for environment, personal health and money on various forms of pro-environmental consumption, namely simple buying, green buying, energy saving and recycling. Furthermore, the paper aims to investigate interrelation between those forms of pro-environmental preferences and actions. Data was collected through a survey on a sample consisting of high-educated 271 consumers living in Turkey. Results revealed that, environmental concern, a widely recognized antecedent, did not foster all forms of pro-environmental behaviors while it had a weak, but still significant effect on green buying and energy saving. Simple buying was promoted by only economic concern. Finally, and importantly green buying was found to be promoting the other pro-environmental actions at the following stages of the consumption process such as energy saving and recycling.
\end{abstract}

Keywords : Pro-environmental consumption, environmental concern, economic concern, health concern JEL Classification : M30, M31, Q56

\section{INTRODUCTION}

"To live is to consume" and its natural consequences are inescapable, as stated by Borgmann (2000). Although the vigorous and growing consumption is seen as the chief indicator of the prosperous and self-confident community (Borgmann, 2000), it also sets a double environmental load; first by the reduction of nonrenewable natural resources, and second by pollution of the air water and soil. Since the 1970s, when the ecological problems stemming from production and consumption process came to surface, it is suggested that consumption patterns need to be altered, lifestyles need to be changed and the ways products and services are extracted, distributed and consumed need to change, as well (Dobers and Strannegard, 2005). Thence, proenvironmental consumption, has been an intersection point of multi-disciplinary scientific researches (environmental engineering, ecological economics, environmental psychology, sustainable marketing, ecological sociology) to find a common answer about how people with different lifestyles, aspirations, economic levels can continue to live without underestimating the ecological threats (e.g. Kassarjian, 1971; Meadows et al., 1972; Menon and Menon, 1997; Sanne, 2002).

The literature to date identified a number of individual and social level factors effective on consumers' proenvironmental behaviors. Knowledge (Gifford and Nilsson, 2014; Gifford, 2014), attitudes (e.g. Kinnear and Taylor, 1973, Roberts, 1996; Kalafatis et al., 1999; Kim and Choi, 2005), values (Stern et al., 1993; Stern and Dietz, 1994, Shultz and Zelezny, 1999; Schultz et al.., 2005; Vermeir and Verbeke, 2008), emotions (Baumeister et al.,1994; Passyn and Sujan, 2006; Hartmann and Apaolaza-Ibanez, 2008; Antonetti and Maklan, 2014; Koenig-Lewis et al.,2014), norms (Griskevicius et al., 2012), beliefs about responsibility and personal control (Ellen et al., 1991; Berger and Corbin, 1992; Vermeir and Verbeke, 2008), habit and routines (Stern, 2000) were 
found to influence pro-environmental consumption. In a hopeful vein, it is assumed that changing people's environmentally careless consumption behavior through managing those influencing factors can potentially make a great contribution towards solving various environmental problems. However, it is remarkably difficult to predict responsible consumer behavior (Ulusoy, 2016) due to supporting and hindering effects of factors that generate individual dilemmas leading to inconsistency between consumers' environmental attitudes and behaviors (Young et al. 2010, Roberts, 1996; Carrigan and Attala, 2001; Chatzidakis et al., 2007; d'Astous and Legendre, 2009; Carrington et al., 2010; Bray et al., 2011). Thus, the need for additional researches on understanding pro-environmental behaviors is often discussed.

Accordingly, this research aims to expand current state of the knowledge in two ways. First, it attempts to demonstrate the relative effects of three different personal motivations. Although the environmental concern is a well-defined predictor (e.g. Kassarjian,1971; Kinnear and Taylor, 1973; Antil,1984; Zimmer et al. 1994; Roberts, 1996; Laroche, 2001; Hartmann; Barr, 2007 and Apaolaza-lbanez, 2012) pro-environmental behavior is not an automatic result of environmental concerns, but there is gap between people's environmental concerns and possible actions (Gifford and Nilson, 2014; Binder and Blankenberg, 2016). As addressed by Sheth et al. (2011) there are three kinds of caring sense including care for self, care for nature and community that motivate one's pro-environmental consumption behavior. This approach is consisted with the argument that most direct role of the consumption is to increase the living standards of consumers (Goodwin et al.2008), and consumers are more motivated by self-interest than by the interest of society. So, this research focuses not only on environmental concern but also some other selfish concerns including health concern, economic concern to provide a more comprehensive understanding of pro-environmental actions. Second, rather than a general pro-environmental behavior, we focus on explaining diverse forms of pro-environmental consumption activities from different stages of consumption process. Accordingly, simple buying, green buying (form preconsumption stage), energy saving (from during consumption stage) and recycling (from post-consumption stage) are investigated. In this way, unlike prior research, the interrelationships between different proenvironmental consumption behaviors are also investigated.

Knowledge about the relative roles of the various motivating concerns for various pro-environmental behaviors may have important managerial implications for the policy makers; NGO's that work for encouraging environmental consumption practices and companies who pursue environmental marketing. Finally the evidence regarding the interrelation of behaviors from different stages (before, during and after consumption) is likely to provide an enlarged view of pro-environmental consumption behavior.

\section{LITERATURE REVIEW}

\subsection{Pro-environmental Consumption Behavior}

In the literature there are interrelated, interchangeable, overlapping concepts which define the preferences or behaviors motivated to reduce the negative impacts of consumption on environment. Sustainable consumption (Cohen, 2001), socially responsible consumption (Roberts, 1995), environmentally significant consumption (Stern, 2000), conscious consumption (Ellen et al., 1991), and mindful consumption (Sheth et al., 2011) can be cited among these concepts. In this study we use pro-environmental consumption concept referring to behaviors that harm the environment as little as possible, or even benefit the environment (Steg and Vlek, 2009). The concept covers various responsible choices and actions in consumption domain such as simple buying, green buying, energy saving, recycling that occur in different stages of a consumption process. Accordingly, simple consumption and green buying appear as pro-environmental activities in pre-consumption stage, energy saving as a during-consumption stage activity and recycling as a post consumption proenvironmental behavior. All these pro-environmental behaviors are likely to change the availability of materials or energy from the environment or alter the structure and dynamics of ecosystems or the biosphere (Steg and Vlek, 2009). In order to encourage pro-environmental consumption, it essential to recognize the triggering motivations for those various choices and actions from diverse stages of consumption process. 


\subsubsection{Green Buying}

Green consumption concept which first became obvious in 1970s (Kassarjian, 1971; Henion,1972; Peattie,2010,p.197) is related with green products and green consumers. Green products can be described as products striving to protect or to enhance the natural environment by conserving energy and/or resources and reducing or eliminating the use of toxic agents, pollution, and waste (Ritter, et al. 2015). Accordingly, green consumption is defined as buying and consuming products which harmless to the environment (Mainieri et al., 1997; p.190; Roberts and Bacon, 1997 p.84; Thogersen and Olander, 2002). Finally, green consumer may be described as the individuals whom buying behavior is effected by environmental concerns (Shrum, 1995), who only buy environmentally friendly product and recycle (Laroche 2001, p.507). Numerous researches focus on to describe who "the green consumers" are and which dynamics are having role on their green buying.

Awareness about environmental issues and disruption have contributed to raising environmental consciousness, buying more environmentally friendly, green products and services (Kaufmann et al., 2012). Actually, related with the awareness, environmental concerns of consumers are found to be the most important predictor of green buying behavior (Arbuthnot and Lingg, 1975; Minton and Rose, 1997; Mainieri et al., 1997; Kim and Choi, 2005; Ishaswini and Datta 2011Lee et al., 2014; Zhao et al.,2014; Pagiaslis and Krontalis, 2014). Moreover increases in individuals' awareness of environmentally friendly products also promote green buying (Ishaswini and Datta 2011). Previous studies offer empirical evidence regarding the influence of demographics, knowledge, values, attitudes and behavior on consumers' willingness to pay more for environmentally friendly products (Laroche, 2001). Specifically, collectivism (Kim and Choi, 2005), perceived consumer effectiveness (Kim and Choi, 2005), environmental knowledge (Chan and Lau, 2000), product information (Joshi and Rahman, 2015), health concern (Magnusson, 2003) were found to increase green consumption.

\subsubsection{Simple Consumption}

Simple consumption, which may be interpreted also as "simplifiers" variant of anti-consumption lifestyle, is founded on "choosing to limit material consumption in order to free an individual's resource, like money and time, to seek satisfaction through nonmaterial aspects of life" (Huneke, 2005; Etzioni, 1998; Iyer \& Muncy, 2009). For a variety of social and political reasons limiting or reducing the consumption is not a favorable approach for political and economic leaders (Bowerman, 2014). However, including a minimum reasonable level of consumption, simplifying the life and reducing consumption with the goal of greater sustainability may be beneficial to society (Seegebarth et al., 2015) and to ecological problems such as climate change (Bowerman, 2014). Despite the various interpretations of voluntary simplicity profiles, several authors have agreed upon the core values of this lifestyle which are "material simplicity, self-determination, self-sufficiency, ecological awareness, social responsibility and spirituality and personal growth" (e.g. Elgin and Mitchell, 1977; Etzioni, 1998; Huneke, 2005; Shaw and Moraes, 2009). Voluntary simplifiers are more inclined than others towards pro-environmental consumption behaviors (e.g. limiting car use, buying environmentally friendly products, composting, buying organic foods, recycling) because they are more satisfied with these activities than with a materially or conspicuously motivated consumption behavior (Etzioni, 1998; Huneke, 2005). Furthermore, Shaw and Newholm (2002) highlight ecological advantages of voluntary simplicity (like energy saving, extending a product's life) for environment obtained from car sharing, product sharing, reusing, repairing and second hand goods consumption.

\subsubsection{Energy Saving}

Probably due to the improvement in the standard of living and people's greater demands in terms of comfort the energy consumption has significantly increased in both developed and developing countries over the years (Paço and Varejao, 2010). Since 1970s, energy conservation is a topic of interest for social and environmental psychology due to raising concern about energy crisis and environmental problems such as global warming and threats to biodiversity (Abrahamse et al. 2005). Accordingly, domestic energy consumption generates a significant proportion of anthropogenic global carbon emissions (Vivian et al., 2011), increases the global warming and threats biodiversity (Abrahamse et al. 2005). Additionally, the sudden increase in energy prices following the oil embargo crisis in 1973 has urged all the stakeholders (scientists, consumers, companies, 
politicians, governments, NGOs) to consider the importance of energy resources' constraints despite their actual diversification (from fossil fuel -oil, natural gas, coal- to nuclear energy, wind and solar energy) (Stern, 1992). Henceforth, the environmental concerns (e.g. Verhallen and Van Raaij, 1981) and economic concerns (e.g. Barr et al. 2005) triggered by actual energy resources restraints and human-induced problems forced many businesses and consumers to assume a more environmentally responsible attitude and involve in more pro-environmental behaviors (Gadenne, 2011; Karlin et al., 2014). Considering its environmental and economic costs, individual energy conservation has become a significant focus for the research worldwide due to its potential contribution to solving the problem (Yue et al., 2013)

As an important green consumption indicator with diversified activities (e.g. decreasing use, purchasing energy efficient appliances) energy conservation is promoted by environmental knowledge (Abrahamse et al. 2005), through regular information-or feedback (Steg, 2008; Carrico and Riemer, 2011, Allcott, 2011) or via peer education (Carrico\&Riemer, 2011). Differently from the other green consumption practices, it is not easy to generalize socio demographic antecedents of energy conservation as it covers a large assortment of behaviors (Painter et al, 1983; Black et al., 1985; Sütterlin et al, 2011). Similar to other pro-environmental consumption behaviors, personal norms (Gadenne et al, 2011; Testa et al, 2016) and social (descriptive) norms (Black et al., 1985; Niemeyer, 2010; Allcott, 2011) influence energy saving behaviors positively. As classified by Stern (2000), altruistic and biospheric personal values are also displayed as strong motivators of energy saving measures (Poortinga et al., 2004; De Groot and Steg, 2008). Consistent with Value-Belief-Norm Theory (Stern, 2000), these personal values increase consciousness and activate the consumers' ascription of responsibility for these problems, which consecutively increase their contribution to problem solution, in an indirect way, e.g. recognition and application of energy policies (Steg et al., 2005) or a direct way, e.g. household energy use (Poortinga et al., 2004). Correspondingly, Oikonomou et al. (2009) showed that environmental comfort and quality of future generations, as an important moral responsibility, reinforced energy saving behaviors of the actual consumers.

\subsubsection{Recycling}

Inasmuch as environmental issues have amounted to vital degree for individuals, the interest in recycling activities in particular solid waste recycling has increased (McCarty and Shrum, 1994, p.53). Recycling is defined as " the diversion of products /packages from the waste stream (Ellen,1994), "which materials previously used are collected, processed, remanufactured and reused" (Schultz et al.,1995,p.105). As a post-purchase behavior, recycling involves bringing things (such as newspapers, plastics, bottles and cans) to recycling collection points (Minton and Rose,1997; Yavetz et al., 2009), buying products made from reusable packages and combing out garbage (Roberts and Bacon, 1997). From environmental perspective, recycling conserves limited natural resources; reduces and rationalizes the problems of managing municipal solid waste disposal (Dainelli, 2003). More specifically, as stated by Largo-Wight, et al. (2012) recycling municipal waste reduces the need to harvest raw material for production, reduces emissions from waste incinerators and landfills, and reduces production-related energy use.

In previous researches certain factors (demographics, attitude, providing reward, removing barriers, and normative influence) which influence the proportion of individuals who recycle, have been investigated (Schultz et al., 1995). Other factors investigated as related with recycling behavior are demographics, personality and situational variables (Lindsay and Strahtman, 1997). Awareness and information about recycling, easiness, economic incentive, attitudes toward recycling, local norms and regulations may be sorted as factors which can affect recycling behavior (Gifford,2014). Also there are empirical findings about the crucial role of environmental concern for recycling behavior (Kim and Choi, 2005). Moreover, a significant relation has been found between organic food consumption and recycling which were explained by environmental values and concerns etc. (Peattie, 2010). 


\subsection{Motivations of Pro-Environmental Consumption}

\subsubsection{Environmental Concern}

Environmental concern (EC), originated from the people's reference to "a whole range of environmentally related perceptions, emotions, knowledge, attitudes, values and behaviors" (Bamberg, 2003) has been studied within pro-environmental consumption research literature over five decades (e.g. Kassarjian,1971; Kinnear\& Taylor, 1973; Antil,1984; Zimmer et al. 1994, Roberts, 1996, Laroche, 2001, Hartmann and Apaolaza-Ibanez, 2012). After the scientific recognition of the fact that Earth's ecological balance was under huge threat (e.g. Meadows et al., 1972), EC has emerged as a concept expressing an individual's pro-environmental sensitivity and attitude (Maloney and Ward, 1973; Weigel and Weigel, 1978). EC was found to be predicted by one's education level (Van Liere and Dunlap, 1980); age (Van Liere and Dunlap, 1980), knowledge (Stern, 1994), values (Schultz and Zelezny 1998), personal norms and perception about personal responsibility (Stern, 2000) etc. On the other hand, EC has been a critical factor impacting consumption choices and actions. A metaanalysis by Hines et al. (1987) revealed that EC is one of the six main predictors of pro-environmental behavior. Early researches showed that consumers' EC served as an attitude that influenced the consumption intention (e.g. Kassarjian, 1971; Kinnear and Taylor, 1973; Antil, 1984). Beside its general promoting impact on general pro-environmental consumption tendency, literature also provides evidences regarding the effects of EC on more specific behaviors in consumption process. For instance, Kim and Choi (2005) found that EC, with the coindicators collectivism, perceived consumer effectiveness, promoted pro-environmental behaviors such as buying ecological products and avoiding products which are harmful to other people and the environment. Not only preferences but also amount of the consumption is likely to change in favor with environment, as a consequence of high level of EC. In this context, simple consumption (downshifting as a part of voluntary simplicity) offered a new path for reducing the negative effect on the environment (Etzioni, 1998; Shaw and Newholm, 2002; Huneke, 2005). Iwata (1999) found a positive relationship between ecological consciousness, health consciousness and thoughtful attitudes in consumption behavior within the voluntary simplicity context. Furthermore, Iwata (2001) reported a positive relationship between self-rated environmentally responsible attitude and mindful spending behavior. Simplifiers have often addressed the minimal use of earth's resources as the reason of using second hand furniture, clothes, and repairing rather than replacing damaged items (Craig-Lees and Hill, 2002) These findings suggested that as consumers' sensitivity about environmental treats was likely to reduce the amount of the new product consumption.

High level of concern about the environment also seems to chance the daily actions on waste management. Barr (2003) found that EC was among one of the principal factors to increase the awareness and intention of recycling. Beside, "concern for waste", introduced as a special types of environmental concern by Zimmer et al. (1994), provided a more specialized way for positive relationship between concern and recycling behavior.

Following the energy crisis in 1970s, EC has been among the important factors to involve consumers in energy related problems and to personalize these problems in their daily life (Seligman et al, 1979; Leonard-Barton, 1981; Zimmer et al., 1994; Barr, 2005). Poortinga et al. (2004) concluded that environmental concern accompanied by personal values had a positive impact on the acceptability of household energy saving behaviors. Gadenne et al (2011) suggested that there was a strong relationship between energy saving behavior and environmental concern as an attitude.

Therefore, we propose that environmental concern encourages consumers to exhibit all kind of proenvironmental choices and actions through consumption process including pre, during and post consumption stages:

H2: Environmental concern has a positive influence on simple buying behavior.

H3: Environmental concern has a positive influence on recycling behavior.

H4: Environmental concern has a positive influence on energy saving behavior. 


\subsubsection{Health Concern}

Although there are some other factors, environmental problems such as pollution (e.g., water, air, soil), climate change are introduced as substantial sources of public health problems through various diseases (Schreinemachers and Ghio ,2016; Frumkin et al. 2008). Individuals who perceive environmental issues as a serious threat for their health, tend to be more in environmental behavior activities like recycling, water conservation and purchasing environmentally friendly products (Baldassare and Katz, 1992). Accordingly, consumers with a relatively high level of health concern are expected to have a stronger tendency for those pro-environmental behaviors. Consistently, Turen and Ganes (2012) found that health consciousness had a positive relationship with pro-environmental behaviors.

Health concern is conceptualized as the consumer's concern for quality of life, health issues and the environment for humans and non-human species (Qader and Zainuddin, 2010) and health consciousness is the degree to which health concern is integrated into a person's daily activities (Jayanti and Burns, 1998) including buying, consuming and disposing. As reported by Qader and Zainuddin (2010) safety and health concerns are considered as the strongest predictor of attitude and behavior supporting to those researchers who claim that increasing concern with health and safety are becoming prominent factor in shaping people's attitudes towards the environment. In a similar vein we propose health concern to be related with proenvironmental behaviors, more specifically with green buying (because of its direct effect on individual health) and recycling (due to its indirect effect on individual health through pollution, and other negative environmental outcomes).

Previous researches provide empirical evidence on the indirect effect of health concern on behavioral intention to buy green products through promoting environmental attitudes (Qader and Zainuddin, 2010). When considering the direct relationship it was reported that individuals who perceived environmental issues as a serious threat against their health, tended to exhibit environmental behavior activities like recycling, water conservation and purchasing environmentally friendly products (Baldassare and Katz, 1992). When persons with health concern buy products, they think more of their environmental consequences and are generally much more protector than the others in environmental issues (Rundmo, 1999). Health as an individual value has also been revealed as an indicator of buying green products (Joshi and Rahman,2015). Moreover, organic buying is investigated as another consequence of health concern (Magnusson et al.,2003; Michaelidou and Hassan, 2008; Kriwy and Mecking, 2012) probably because the organic food is perceived as healthier, safer and environmental friendly than the conventional one (Irianto, 2015). Although environmental concern affects buying organic products, health is more raid motive for buying organic foods and affecting attitudes. (Michaelidou and Hassan,2008). For this reason we suggest that consumers with a high level of concern about personal health will buy more green products:

H5: Health concern has a positive influence on green buying behavior.

In addition to the green buying, recycling is addressed as another pro-environmental behavior in consumption domain that improve environmental quality for the health of the public (Largo-Wight, 2012). Granzin and Olsen (1991) found that common threats provided by environmental pollution were among the sources of motivation toward environmental protection activities like recycling. In a survey conducted among adult consumers in USA, Baldassare and Katz (1992) found that serious environmental threats against personal health and well-being have significantly increased the tendency of engaging in recycling and other proenvironmental behaviors. Furthermore, Rundmo (1999) displayed a significant relationship between health concern and recycling behaviors. Similarly, McCarty and Shrum (2001) stated that environmental beliefs about recycling's impact on environmental pollution supports positively recycling behaviors. Consequently, we propose that health concern positively influences recycling behaviors since recycling is considered as a form of primary prevention that protects the environment and natural resources and therefore protects and promotes the health of the public (Largo-Wight et al. 2012) .

H6: Health concern has a positive influence on recycling behavior. 


\subsubsection{Economic Concern}

Economic reasons, including the "financial security" need (Richins and Dawson, 1992), "price and value consciousness", (Lastovicka et al., 1999), "economic rationality" (d'Astous and Legendre, 2009) symbolize the dominance of economic concerns in consumers' decision processes and thus play a role for pro-environmental decisions. Frugality, another reflection of economic concern and defined as a lifestyle characteristic reflecting sacrifice in short-term consumption, is another self-controlled purchase behaviors based on individual constraints (Lastovicka et al., 1999; Rick et al., 2008; Pepper et al., 2009). It is also defined as a trait that reflects" the extent to which individuals are restrained in acquiring and resourcefully using goods and services to achieve their long-term goals" (Bove et al., 2009) and found to be related positively with the behavioral traits of value and price consciousness (Shoham and Brenčič, 2004). In this study "economic concern" refers to show more discipline in spending money and resourceful in product and service acquisition, use, and reuse similar to the frugality definition of Witkowski, 2010 and Shoham and Brenčič, 2004. Literature provides some empirical support regarding the economic concern and pro-environmental attitudes and behaviors. Gadenne, et al. (2011) found that economic concern is a significant indicator of environmental attitudes. From the opposite perspective economic rationalization appears as justification mechanism for behaving irresponsibly (d'Astous and Legendre, 2009). Also in this research we expect economic concern to be positively related with consumption reducing forms of pro-environmental behaviors since it leads to consume more carefully, thoughtfully, and with greater restraint (Witkowski, 2010).

First form of the pro-environmental behavior proposed to be motivated by the economic concern is simple buying which refers to the exchange, borrowing, repairing, making products, or buying second hand product instead of buying new products. As stated by lyer and Muncy (2009) "simplifiers" are motivated by individual economic concern as well as environmental concern. Nepomuceno and Laroche (2015) found that frugality and voluntary simplicity had a negative relationship with personal debt and positive relationship with account balances. In a similar vein, within the anti-consumption context, Ozanne and Ozanne (2009) and Ozanne and Ballantine (2010) demonstrated that frugality, economic concern, had an impact on a group of consumers with different profiles ("Socialites, Market Avoiders, Quiet Anti-Consumers and Passive Members") who decreased consumption through sharing in toy libraries rather than possessing. Henceforth, we propose that:

\section{H7: Economic concern has a positive influence on simple buying behavior.}

Also, energy use of consumers is closely related with the price of natural gas, fuel oil, or electricity (Raaij and Verhallen,1983) and consequently with economic concerns. Heslop et al (1981) showed that from the attitudinal factors such as social responsibility, energy and environmental consciousness, only price consciousness (that can be interpreted as economic concern) appeared as related to energy consumption behavior. Olsen (1981) suggested that, as a part of "anticipated personal consequences", money saving accompanied by the motive to help solving energy problem were critical factors in explaining household energy saving. Additionally, Fujii (2006) demonstrated that attitude toward frugality had positive effects for gas and electricity reduction behaviors. More directly, following environmental concern cost of energy is the second most influential factor for energy saving (Paço and Varejao, 2010). Martin et al. (2011) indicates that particularly low-income households have strong incentives to save energy due continually rising energy prices. Most recently, Testa and Iraldo (2016) report that financial motivation has a significant role for curtailment energy saving. Based on these evidences, we hypothesize that there is positive relationship between economic concern and energy saving behavior.

H8: Economic concern has a positive influence on energy saving behavior.

Contrary to fostering impact of economic concern on energy saving and simple buying we suggest its hindering role for green buying. Economic arguments, mainly based on initial cost and long payback time, have been referred as significant barriers for green buying in many researches (Caird et al., 2008; Gardner and Stern, 2008; Niemeyer, 2010; Young et al., 2010). Particularly, the perceived higher price of the green product were found to be prominent indicator of buying non-green (Gleim et al., 2013). Sheth et al. (2011) stated that the lower market shares of green products were due to quality compromise, low availability and high costs. Faiers and Neame (2006) concluded that financial characteristics (immediate cost vs. long term payoff) of the pro- 
environmental solar systems stood as a block against their adoption despite the consumers' favorable attitude. Consumers are expected to be reasonably price insensitive to buy green products (Johnstone and Tan, 2015). Furthermore, consumers who are focused on price and quality, have denied the additional cost of pro environmental products (fair trade goods, ecological goods) that are perceived as lower quality (d'Astous and Legendre, 2009). Stern (2000) has concluded that these difficulties based on economic reason impeded pro environmental behaviors by strengthening the mostly recognized attitude-behavior gap. Finally, He et al. (2015) found that consumers' perceptions about their economic capability had a significantly negative effect on the typical non-green consumption behavior. In a similar vein, we propose consumers with high level of discipline in spending money are likely to focus on the costs of the green products and be unwilling pay a higher price for green products:

H9: Economic concern has a negative influence on green buying behavior.

\subsection{The Interrelation of Different Pro-Environmental Behaviors}

Cognitive Dissonance Theory (Festinger, 1957), suggests that there is an inner drive to hold all our attitudes, beliefs and behaviors in a harmony. Accordingly, people who exhibited a social responsible action, consisted with their pro-environmental attitude, are likely to exhibit another forms of responsible consumption which is consisted with the same attitude. Individuals, who have pro-environmental attitudes, really recycle, buy recyclable products and put to use environmentally friendly practices in their house (Gadenne, 2011). Supporting this prediction, in many researches, various type of pro-environmental behaviors were found to be correlated so that they were often considered as reflections of a responsible mindset. For instance, some researchers found that green buying, energy saving and recycling are various assets of green/proenvironmental consumption (i.e Gilg et al., 2005; Gadenne,2011, ). In a similar vein, in the work of Doğan et al (2015), environmental- green purchasing, reverse form of simple buying, energy saving and recycling were introduced as correlated dimensions of sustainable consumption. Alike with the previous researches we use a process approach to clarify the antecedent- consequents relations between various forms of proenvironmental. It seems logical to expect that previous actions in consumption process, namely green buying and simple buying (actions in pre-consumption stage) may foster the related later actions such as recycling and energy saving (actions in consumption and post consumption stages). Supporting our expectations, energy saving was found to be affected by other forms of environmental behavior (Hori et al., 2013). Biswas et al (2000) found a significant relationship between green purchase behaviors, called as "recycling shopping behavior" (e.g. organic food consumption, recyclable product consumption), and waste recycling behaviors. Respectively, Pedersen (2000) found a significant positive relationship between organic food consumption, as part of green purchase behavior and recycling practices (e.g. "recycling bottles and papers"). Thogersen and Olander (2006) found a significant positive relationship between organic food consumption and recycling behaviors. Zhao et al. found that knowledge of green consumption, attitudes toward green consumption, environmental concern, perceived consumer effectiveness, external moderators, purchasing and using behavior had a positive relationship with recycling behavior (2014). Green consumers are interested more daily activities like turning out the lights and recycling papers, newspapers etc. (Young, 2010). Moreover, Thogersen and Noblet (2012) found that consumers' daily "green" consumption behaviors made "a significant contribution to predicting acceptance of wind power when controlling for environmental concern" that is commonly motivating green consumption behaviors and energy saving behaviors. Additionally, green purchase habits and sustainable lifestyles (e.g. recycled paper consumption, organic food consumption) are also displayed as initiators of energy saving behaviors (Gilg et al., 2005). Henceforth, we propose a positive effect of green buying behavior on recycling and energy saving behaviors.

H10: Green buying has a positive influence on recycling behavior.

H11: Green buying has a positive influence on energy saving behavior.

Furthermore simple buying and energy saving are likely to be related based on the "reducing" principles they pursue. Indeed, as an essential topic that has been studied since 1970s (e.g. Kinnear et al., 1974) within proenvironmental consumption context, energy saving has been identified through different characteristics such as consumption reduction. Ecological awareness, described as one of the key interdependent values of 
voluntary simplicity by Elgin and Mitchell (1977), has focused on energy conservation with other environmental protection behaviors such as reduction of pollution and waste (Huneke, 2005; Mcdonald et al., 2006). LeonardBarton (1981) also concluded that many voluntary simplicity behaviors (e.g. change oil in car, bike to work, bike on errands) were in relationship with reduction in energy consumption and also alternative energy systems. Similarly, Olsen (1981) found that voluntary simplicity values had a significant positive relationship with energy conservation behaviors. Based on the importance given to resource conversation, it is expected that consumers who adopt a lifestyle with simplistic consumption choices are likely to exhibit energy saving behavior:

H12: Simple buying has a positive influence on energy saving behavior.

\section{Figure 1: Research Model}

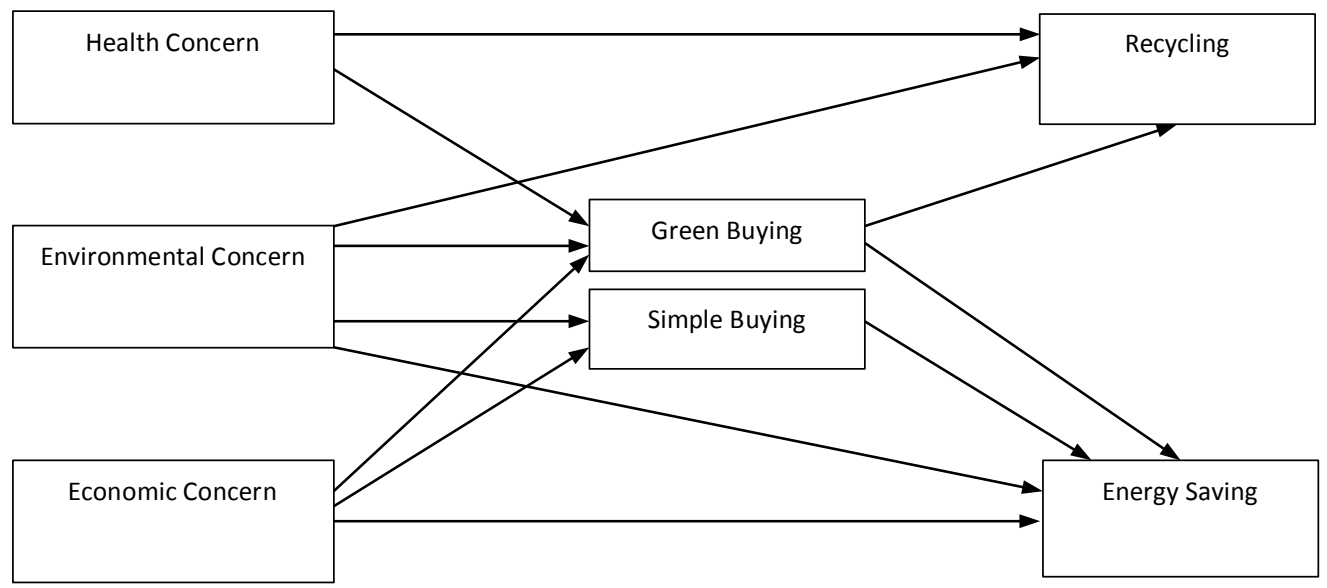

\section{DATA AND METHODOLOGY}

The research hypotheses were empirically tested using the data collected through a survey on a sample consisting high educated Turkish consumers. Respondents were undergraduate and graduate students from various universities located in Kocaeli and İstanbul and consumers having undergraduate degree, at least. A total of 271 valid responses were obtained from participants who were selected using convenience sampling method. Descriptive statistics for the sample is presented in Table 1.

Table 1: Descriptive Statistics

\begin{tabular}{|l|l|l|l|}
\hline Occupation & Valid Percent & Marital Status & Valid Percent \\
\hline Student & 43,0 & Married & 34,9 \\
\hline Private sector & 28,9 & Single & 65,1 \\
\hline Public sector & 20,0 & Income (Turkish Lira) & Valid Percent \\
\hline Self-employment & 2,2 & Less than 2.000 & 12,3 \\
\hline House-wife & 3,3 & $2.000-5.000$ & 43,9 \\
\hline Other & 2,6 & $5.000-10.000$ & 30,1 \\
\hline & & More than 10.000 & 13,8 \\
\hline
\end{tabular}


Dependent variables were measured using multi-item scales that are obtained through combining the previously used items. Energy saving behavior was measured using a twelve-item scale combined of the selected items from the scales of Yavetz et al. (2009), Straughan and Roberts (1999), Roberts and Bacon (1997), Pinto et al. (2014). Ten items were adapted from the scales of Roberts and Bacon (1997), Pinto et al. (2014), Laroche et al. (2001), Choi and Kim (2005), Kilbourne and Pickett (2008) and Pagiaslis and Krontalis (2014) to measure green buying behavior. For the assessment of simple buying a total of nine items were drawn from the scales of Huneke, M. E. (2005), Pepper et al. (2009), Richins and Dawson (1992) and LeonardBarton, D. (1981). A seven-item recycling scale was obtained by combining the items from Huang et al. (2014), Berger and Corbin (1992), Yavetz et al. (2009) and Pinto et al. (2014).

Economic concern, one of the independent variables, was measured using five items adapted from the "frugality scale" of Lastovicka et al. (1999). Health concern was measured through a six item measurement scale previously used by Jayanti and Burns (1998). Last independent variable, environmental concern was assessed using four items that were adapted from Berger and Corbin (1992), and Dunlap et al. (2000). All constructs were measured through five point Likert type scales with the response anchors $1=$ Strongly Disagree and $5=$ Strongly Agree. Finally, demographic information was asked including, occupation, education and income.

Validity of the scales was evaluated through exploratory factor analysis. A total of 46 items were subjected to principle components analysis using oblique rotation. Through a step-by- step procedure problematic items were eliminated from the measurement model due to their factor loadings lower than .500 and/ or cross loadings to irrelevant factors. After the elimination of 14 items the analysis resulted in seven factors explaining $60 \%$ of total variance As presented by Table 2 factor loadings for the items of green buying, recycling, economic concern, health concern, environmental concern were larger than .600 providing support for validity. Moreover, Cronbach's Alpha coefficients were above 0.70 indicating those constructs were reliable according to the criteria indicated by Nunnaly (1978). Although relatively low factor loadings and Cronbach's Alpha coefficients with .60 and .69 respectively, energy saving and simple buying variables were not eliminated from the model because of theoretical importance of these variables.

Table 2: Factor Loadings and Reliability Scores

\begin{tabular}{|c|c|c|}
\hline Factors/Items & $\begin{array}{l}\text { Factor } \\
\text { loadings }\end{array}$ & $\begin{array}{l}\text { Cronbach's } \\
\text { Alpha }\end{array}$ \\
\hline Simple Buying & & .69 \\
\hline B29- Exchange goods or services & ,785 & \\
\hline B27- Give or lend to friends or relatives & ,695 & \\
\hline $\begin{array}{l}\text { B28- Have gotten instruction in skills to increase self-reliance, for example, in carpentry, car tune-up and } \\
\text { repair, or plumbing }\end{array}$ & 669 & \\
\hline B31- Buy second hand furniture & ,593 & \\
\hline B30- Make gifts instead of buying & ,568 & \\
\hline Green Buying & & .79 \\
\hline B5- I make every effort to buy paper products made from recycled paper. & 787 & \\
\hline B6- I make special effort to buy plastic products that are made from recycled materials. & ,780 & \\
\hline $\begin{array}{l}\text { B1- Generally I prefer to purchase product with little reusable-recycling packaging ( } 1 \text { try only to buy } \\
\text { products that can be recycled. }\end{array}$ & 766 & \\
\hline B11- I prefer to buy things out of woods and other natural resources or at least biodegradable material. & ,686 & \\
\hline B9- I buy organic food whenever possible. & ,649 & \\
\hline Energy Saving & & .60 \\
\hline A2- I turn the heat/air conditioning system off in unused rooms. & ,729 & \\
\hline A1-I keep heating/air conditioning low to save energy. & ,670 & \\
\hline A3- Leave the air conditioner off when I leave the room & ,635 & \\
\hline A12- I buy high efficiency but expensive light bulbs to save energy & ,615 & \\
\hline Recycling & & .83 \\
\hline B17- I bring things (such as newspapers, plastic and glass bottles) to recycling collection points & ,876 & \\
\hline B13-I keep my garbage in separate piles of glass, plastic, paper, metal fo recycling & ,863 & \\
\hline B14- He/she recycles garbage at home, at work, and at his/her holiday destinations. & 729 & \\
\hline
\end{tabular}


B18- I disposed of used batteries in proper collection container instead of waste basket

C26- People are only sharing the Earth with other creatures and we have no right to use it as suits us , 805 C23- I am extremely worried about the state of the world's environment and what it will mean for my ,765 future,

C25- When humans interfere with nature, it often produces disastrous consequences

,751

\section{Health Concern}

C21- I am interested in information about my health.

C22- I am concerned about my health all the time.

C20- I read more health-related articles than I did 3 years ago.

C19-I usually read the ingredients on food labels.

\section{Economic Concern}

C15- I am willing to wait on a purchase I want so that i can save money

C16- There are things I resist buying today so I can save for tomorrow

Having ensured validity and reliability of the measures all multiple-indicant variables were transformed into composite scores to be used in path analysis. Scale means, standard deviations, and inter-correlations were presented in Table 3. Then, the research model shown in the Figure 1 was tested using maximum likelihood estimation technique. Estimation resulted in an acceptable model fit $(\chi 2(6)=12,398, p=.054, \chi 2 / d f=2.066$; $\mathrm{GFI}=.987, \mathrm{NFI}=.966, \mathrm{CFI}=.982$ and $\mathrm{RMSEA}=.063)$. The path analysis results for the proposed relationships were displayed in Table 4.

Table 3: Construct means, standard deviations and inter-correlations

\begin{tabular}{|c|c|c|c|c|c|c|c|c|c|}
\hline & Mean & SD & (1)EC & (2) HC & (3)EC & (4)GB & (5)SB & (6)ES & (7)RC \\
\hline (1) Economic Concern (EC) & 4.0705 & .79960 & 1 & & & & & & \\
\hline (2) Health Concern (HC) & 3.7393 & .88080 & $.529^{\mathrm{a}}$ & 1 & & & & & \\
\hline (3)Environmental Concern(EC) & 4.2626 & .80100 & $.487^{\mathrm{a}}$ & $.486^{\mathrm{a}}$ & 1 & & & & \\
\hline (4) Green Buying (GB) & 2.8273 & .81827 & $.219^{\mathrm{a}}$ & $.306^{\mathrm{a}}$ & $.288^{\mathrm{a}}$ & 1 & & & \\
\hline (5) Simple Buying (SB) & 2.5571 & .73252 & $.147^{b}$ & .040 & .095 & $.206^{\mathrm{a}}$ & 1 & & \\
\hline (6) Energy Saving (ES) & 3.3506 & .95831 & $.324^{\mathrm{a}}$ & $.219^{a}$ & $.302^{\mathrm{a}}$ & $.282^{\mathrm{a}}$ & $.154^{b}$ & 1 & \\
\hline (7) Recycling (RC) & 3.0323 & 1.08592 & .118 & $.231^{\mathrm{a}}$ & $.226^{\mathrm{a}}$ & $.486^{\mathrm{a}}$ & .115 & $.147^{b}$ & 1 \\
\hline
\end{tabular}

Table 4: Standardized path coefficients for hypotheses

\begin{tabular}{|c|c|c|c|c|c|}
\hline Hypothesis & Structural path & $\begin{array}{l}\text { Standard } \\
\text { Estimate }\end{array}$ & $t$ value & $\begin{array}{c}p \\
\text { (one-tailed) }\end{array}$ & Results \\
\hline $\mathrm{H} 1$ & Environmental Concern $\rightarrow$ Green Buying & .176 & 2,565 & .005 & Supported \\
\hline $\mathrm{H} 2$ & Environmental Concern $\rightarrow$ Simple Buying & .03 & .442 & .329 & Not supported \\
\hline $\mathrm{H} 3$ & Environmental Concern $\rightarrow$ Recycling & .067 & 1,086 & .139 & Not supported \\
\hline $\mathrm{H} 4$ & Environmental Concern $\rightarrow$ Energy Saving & .144 & 2,208 & .014 & Supported \\
\hline H5 & Health Concern $\rightarrow$ Green Buying & .208 & 2,938 & .002 & Supported \\
\hline $\mathrm{H} 6$ & Health Concern $\rightarrow$ Recycling & .061 & .992 & .161 & Not supported \\
\hline $\mathrm{H} 7$ & Economic Concern $\rightarrow$ Simple Buying & .132 & 1,912 & .028 & Supported \\
\hline $\mathrm{H} 8$ & Economic Concern $\rightarrow$ Energy Saving & .205 & 3,184 & .001 & Supported \\
\hline
\end{tabular}




\begin{tabular}{|c|l|c|c|c|c|}
\hline H9 & Economic Concern $\rightarrow$ Green Buying & .023 & .319 & .375 & Not supported \\
\hline H10 & Green Buying $\rightarrow$ Recycling & .448 & 7,97 & .001 & Supported \\
\hline H11 & Green Buying $\rightarrow$ Energy Saving & .181 & 3,113 & .001 & Supported \\
\hline H12 & Simple Buying $\rightarrow$ Energy Saving & .073 & 1,307 & .096 & Not supported \\
\hline
\end{tabular}

\section{FINDINGS AND DISCUSSIONS}

The results suggested that health concern was positively related with green buying behavior $(b=.208, p<.01)$ while its impact on recycling was nonsignificant. Economic concern was found to exert positive and significant effects on energy saving $(B=.205, p<.01)$ and simple buying behavior $(B=.132, p<.05)$ but had no significant influence on consumers' green buying behavior. Environmental concern was found to have significant positive effects on green buying $(B=.176, p<.01)$ and energy saving behavior $(B=.144, p<.05)$. However, it had no significant impact on simple buying and recycling behavior. On the other side, proposed influence of the green buying behavior on the recycling and energy saving behavior found empirical support with $\beta=.448(p<.01)$ and $\beta=.181(p<.01)$, respectively. However, the relationship between simple buying and energy saving was not significant.

From the perspective of responsible consumption behavior, the model explains $12 \%, 16 \%$ and $25 \%$ variance in green buying, energy saving and recycling behavior, respectively. Comparing standardized beta coefficients, health concern appeared as stronger than environmental concern as an antecedent of green buying behavior. Also it seems that not environmental or health related concerns but green buying is a triggering factor for recycling behavior. Considering the relative strength of energy saving indicators, environmental concern appeared as significant but weakest indicator of energy saving behavior while the economic concern has a dominant effect. Finally, the results revealed that the model explained only $2 \%$ of the observed variance in simple buying with the unique promoting influence of economic concern, signaling there are quite different antecedents.

Figure 2: Final Research Model

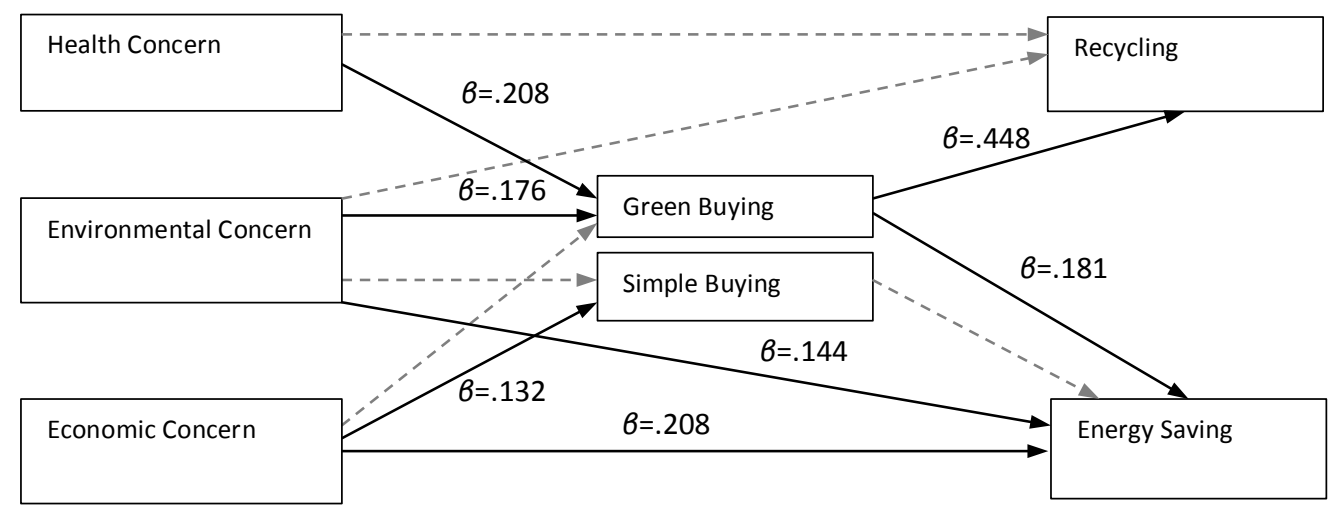

\section{CONCLUSION}

Excessive and careless consumption patterns accelerate the serious environmental problems directly by usage and disposing of the environmentally harmful products and indirectly through triggering production and processing of the material commodities which leads to depletion of natural resources and pollution. Due to the increased concern for the environment a need for substantial changes in consumption behavior on an everyday level was addressed as a critical part of the solution. For more than four decades, behavioral researchers focus on understanding dynamics for more responsible, sustainable, mindful and proenvironmental consumption patterns. In this way, it is assumed that, environmental problems may be managed by changing the relevant behavior so as to reduce its environmental impacts (Steg and Vlek, 2009). In a hopeful vein this study focuses on investigating antecedents of various pro-environmental behaviors. More 
specifically this paper aims to clarify relative role of the consumers' care for nature and community and care for self in their tendency to buy green, buy simple, save energy and recycle. Moreover, we investigate the interrelation between those pro-environmental behaviors.

Results showed that concerns about personal health and environment were main antecedent of green buying behavior while the proposed negative influence of economic concern was not significant. Consistent with the argument of Qader and Zainuddin (2010) concern for quality of life, health issues and safety were found as prominent factor in shaping consumers' preference for natural, organic and recycled products. Additionally, for simple buying behavior the only encouraging factor was found as economic concern while the effect of environmental concern was not significant. Similarly, environmental concern had no impact on recycling while the green buying was the dominant fostering factor. Finally, energy saving behavior had three indicators including economic concern, green buying and environmental concern. Although it has a significant effect, environmental concern has relatively weakest factor take role for energy saving behaviors. It can be concluded that environmental concern has a weaker impact than expected on pro-environmental consumption behaviors.

The encouraging effect of environmental concern, which appears as care for nature and community, is evident in the literature (e.g. Kassarjian,1971; Kinnear and Taylor, 1973; Antil,1984; Zimmer et al. 1994, Roberts, 1996, Laroche, 2001, Hartmann and Apaolaza-Ibanez, 2012). Consisted with previous findings, in this research environmental concern was found to promote green buying and energy saving behaviors. However, economic concern and health concern were found to have a stronger impact than environmental concern on energy and green buying respectively. On the other hand, there is even no correlation between environmental concern and simple buying. It is probably because Turkish consumers do not identify environmental issues related with purchase amount. They need to be informed and convinced about the positive consequences of simple consumption for environment to develop the association. The analysis results revealed that economic concern is the only factor that has a weak but still significant encouraging impact on simple buying. It appears that motivation for "saving money for future" encourages using alternative ways such as exchanging, barrowing, making, repairing the products or at least buying second hand product when needed instead of spending money for new products. Future researches are needed to improve the understanding of Turkish consumers' simple buying behavior since a very small amount of the variance in simple buying was explained. Religious belief may be investigated as an indicator since the frugality (and consequently to avoid purchasing if it not an essential need) is considered as an explicit core virtue in Muslim tradition just like some other religions (Peattie, 2012).

Furthermore, contrary to expectations, environmental concern does not have a significant impact on recycling behavior. Although there is a weak correlation between environmental concern and recycling it was suppressed by the effects of other antecedents in the model. This unexpected finding can be attributed to the perceived cost of recycling stemming from infrastructural problems in Turkey. Recycling is a social impact behavior which involves different stakeholders (e.g. government, consumers, and companies) and differently from usual (or daily) consumer behavior, it has immediate costs (e.g. infrastructure) but long term benefits for all stakeholders (McCarty and Shrum, 2001; Griskevicius et al. 2010). The low cost hypothesis predicts that "the strength of effects of environmental concern on environmental behavior diminishes with the increasing behavioral costs" (Diekmann and Preisendörfer, 2003). Supporting this suggestion a survey, conducted on 400 Turkish consumers living in istanbul, revealed that $55 \%$ of the indicated reasons for not recycling is about lack of appropriate recycling infrastructure (Bayraktar, 2006).

The most important finding of the research was that green buying had a key role for promoting other forms of pro-environmental consumption. Although some previous studies reported the correlation between various forms of the environmentally responsible actions (i.e. Gilg et al., 2005; Gadenne,2011; Doğan et al., 2015) this study showed that promoting impact of green buying is so strong that suppressed the effects of environmental concern and health concern. Similarly, green buying has remarkable influence on energy saving, simultaneously with environmental concern and economic concern while the simple buying did not act as a significant predictor. It appears that, consistent with Cognitive Dissonance Theory (Festinger, 1957), when the green preferences are made at the pre-purchase stage of the consumption consistent with environmental attitudes in spite of their higher prices, people are more likely to exhibit pro-environmental behaviors in the 
following stages consistent with their initial behaviors. Furthermore, green buying decisions may increase energy saving and recycling through promoting consumers' perceived effectiveness by persuading themselves that their individual effort can make a difference in the solution. Thus future researches that include also perceived consumer effectiveness are likely to provide a more comprehensive understanding for triggering role of green buying.

Similar to the green consumption, simple buying as a prior pro-environmental activity was suggested to influence the energy saving as a later activity. However the results revealed that it had no significant impact on energy conserving tendency. Insignificant influence of simple buying on energy saving can be attributed to the "delay discounting", the tendency to think that a problem (like natural resource scarcity) is distant in time that it ceases to directly impact actual consumption behaviors (Thogersen, 2014). Griskevicius et al (2012) explain this tendency with being short-sighted and maximizing the here and now. Griskevicius, Tybur, et al. (2012) showed that asking people to save for the future, when natural resources' expiration time is unknown, leads most people to do the opposite of the expected response, causing them to increase their "valuation of the present" and engage in behaviors with "short-term payoffs". This short-term view may have impeded the expected positive effect of simple consumption on energy saving. Additionally, lack of knowledge (or information that might be accompanied with continuous feedback, rewards) concerning the direct impact of energy saving (Abrahamse et al, 2005; Niemeyer, 2010) may have prevented the positive impact of simple consumption.

In sum, we may presume that consumers' concern about environmental problems may not necessarily be the most important attitudinal factor that promotes the pro-environmental behaviors. There are other self-caring motivations including caring for health and caring for money that foster various forms of pro-environmental behaviors. This result provides useful managerial insights for policy makers and NGO's that work for encouraging environmental consumption practices through persuasive messages. Obviously, messages merely with environmental arguments are likely to fail to motivate consumers for buying less or classify waste of glass, plastic, paper, metal, batteries and take them to proper collection containers since recycling behavior is not influenced by environmental concern. Together with the environmental risks, messages should cover the selfrelated benefits of certain behaviors.

More importantly this research showed that some initial pro-environmental behavior in the consumption process may lead later consistent behaviors. So, it is reasonable to argue that the green buying is the first address for policies aiming to maintain and improve pro-environmental consumption. If consumers are convinced to buy green, they are very likely to recycle and save energy.

Nonetheless, it must be acknowledged that there are several limitations of the research. This study covers only four particular types of pro-environmental behavior, which is a comprehensive concept with diverse dimensions; findings might not be easily transferable to all types of pro-environmental consumption behavior. Hence, additional researches can be conducted on different types of pro-environmental behaviors to ensure the generalizability of findings. Another limitation of this research might be a risk of "social desirability bias" as the analyzed behaviors are "self-reported". Finally, further works should avoid the limitation that current study has due to relatively small and homogenous sample.

\section{REFERENCES}

Abrahamse, W., Steg, L., Vlek, C., \& Rothengatter, T. (2005). “A Review of Intervention Studies Aimed at Household Energy Conservation”. Journal of Environmental Psychology, vol. 25(3), pp.273-291.

Allcott, H. (2011). "Social Norms And Energy Conservation”. Journal of Public Economics, vol. 95(9), pp.1082-1095.

Antil, J. H. (1984). “Socially Responsible Consumers: Profile and Implications for Public Policy”. Journal of Macromarketing, vol. 4(2), pp.1839.

Antonetti, P., \& Maklan, S. (2014). "Feelings that make a difference: How Guilt and Pride Convince Consumers of The Effectiveness of Sustainable Consumption Choices". Journal of Business Ethics, vol. 124(1), pp.117-134. 
Arbuthnot, J. \& Lingg, S. (1975), "A Comparison of French and American Environmental Behaviors, Knowledge, And Attitudes". International Journal of Psychology, vol. 10, pp.275-281.

Baldassare, M., \& Katz, C. (1992). "The personal Threat of Environmental Problems as Predictor of Environmental Practices". Environment and Behavior, vol. 24(5), pp. 602-616.

Bamberg, S. (2003). “How Does Environmental Concern Influence Specific Environmentally Related Behaviors? A New Answer to an Old Question". Journal of Environmental Psychology, vol. 23(1), pp.21-32.

Barr, S. (2003). "Strategies for Sustainability: Citizens and Responsible Environmental Behavior". Area, vol. 35(3), pp.227-240.

Barr, S. (2007). "Factors Influencing Environmental Attitudes and Behaviors A UK Case Study Of Household Waste Management". Environment and Behavior, vol. 39(4), pp.435-473.

Barr, S., Gilg, A. W., \& Ford, N. (2005). "The Household Energy Gap: Examining The Divide Between Habitual-and Purchase-Related Conservation Behaviors". Energy Policy, vol. 33(11), pp.1425-1444.

Baumeister, R. F., Stillwell, A. M., \& Heatherton, T. F. (1994). “Guilt: An Interpersonal Approach". Psychological Bulletin, 115(2), pp. 243267.

Bayraktar, F. S. (2006) Social Responsibility Projects as a Marketing Strategy: A Recycling Approach from the Customer's Perspective, Unpublished Master Thesis, Marmara Üniversitesi Sosyal Bilimler Enstitüsü, İstanbul.

Berger, I. E., \& Corbin, R. M. (1992). "Perceived Consumer Effectiveness and Faith in Others as Moderators of Environmentally Responsible Behaviors". Journal of Public Policy and Marketing, vol. 11 (2), pp.79-89.

Binder, M. Blankenbergc, A-K. (2016)."Environmental Concerns, Volunteering And Subjective Well-Being: Antecedents And Outcomes Of Environmental Activism in Germany". Ecological Economics, vol. 124, pp. 1-16.

Biswas, A., Licata, J. W., McKee, D., Pullig, C., \& Daughtridge, C. (2000). "The Recycling Cycle: An Empirical Examination of Consumer Waste Recycling and Recycling Shopping Behaviors". Journal of Public Policy and Marketing, vol. 19(1),pp. 93-105.

Black, J. S., Stern, P. C., \& Elworth, J. T. (1985). "Personal and Contextual Influences on Household Energy Adaptations". Journal of Applied Psychology, 70(1), pp. 3-21.

Borgmann, A. (2000). “The Moral Complexion Of Consumption”. Journal of Consumer Research, vol. 26(4), pp. 418-422.

Bove, L. L., Nagpal, A., \& Dorsett, A. D. S. (2009). “Exploring The Determinants Of The Frugal Shopper”. Journal of Retailing and Consumer Services, vol. 16(4),pp. 291-297.

Bowerman, T. (2014). "How much is too much? A Public Opinion Research Perspective". Sustainability: Science, Practice, and Policy. vol. 10(1), pp.1-15.

Bray, J., Johns, N., \& Kilburn, D. (2011). "An Exploratory Study into the Factors Impeding Ethical Consumption”. Journal of Business Ethics, vol. 98(4), pp.597-608.

Caird, S., Roy, R., \& Herring, H. (2008). "Improving the Energy Performance of UK Households: Results from Surveys of Consumer Adoption and Use Of Low-And Zero-Carbon Technologies". Energy Efficiency, vol. 1(2), pp. 149-166.

Carrico, A. R., \& Riemer, M. (2011). “Motivating Energy Conservation in the Workplace: An Evaluation of the Use of Group-Level Feedback and Peer Education". Journal of Environmental Psychology, vol. 31(1),pp. 1-13.

Carrigan, M., \& Attalla,A. (2001). "The myth of the ethical consumer - Do ethics matter in purchase behavior?". Journal of Consumer Marketing, vol. 18 (7), pp. $560-578$.

Carrington, M. J., Neville, B. A., \& Whitwell, G. J. (2010). "Why ethical consumers don't walk their talk: Towards a framework for understanding the gap between the ethical purchase intentions and actual buying behavior of ethically minded consumers". Journal of Business Ethics, 97(1), pp. 139-158.

Chan, R. Y., \& Lau, L. B. (2000). “Antecedents of Green Purchases: A Survey in China”. Journal of Consumer Marketing, vol. 17(4),pp. 338357.

Chatzidakis, A., Hibbert, S., \& Smith, A. P. (2007). “Why people don't take their concerns about fair trade to the supermarket: The role of Neutralisation". Journal of Business Ethics, vol. 74(1), pp. 89-100.

Cohen, M. 2001. "The Emergent Environmental Policy Discourse on Sustainable Consumption”. in M. Cohen and J. Murphy (Eds.), Exploring Sustainable Consumption: Environmental Policy and the Social Sciences. pp. 21-37. New York: Elsevier, 2001.

Craig-Lees, M., \& Hill, C. (2002). “Understanding voluntary simplifiers”.Psychology and Marketing, vol. 19(2),pp. 187-210.

Dainelli, D. (2003).Recycling of Packaging Materials in Mattsson B. and Sonesson U. (Eds) "Environmentally-friendly food processing, Woodhead Publishing, Cambridge.

D’ Astous, A., \& Legendre, A. (2009). “Understanding Consumers' Ethical Justifications: A Scale for Appraising Consumers' Reasons for Not Behaving Ethically". Journal of Business Ethics, vol. 87(2), pp.255-268. 
De Groot, J. I., \& Steg, L. (2008). "Value Orientations to Explain Beliefs Related to Environmental Significant Behavior How to Measure Egoistic, Altruistic, and Biospheric Value Orientations". Environment and Behavior, vol. 40(3), pp.330-354.

Diekmann, A., \& Preisendörfer, P. (2003). "Green and Greenback the Behavioral Effects of Environmental Attitudes in Low-Cost And HighCost Situations". Rationality and Society, vol. 15(4),pp. 441-472.

Dobers, P., \& Strannegård, L. (2005). "Design, Lifestyles and Sustainability. Aesthetic Consumption in a World of Abundance". Business Strategy and the Environment, vol. 14(5),pp.324-336.

Doğan, O., Bulut, Z. A., \& Çımrın, F. K. (2015). "Bireylerin Sürdürülebilir Tüketim Davranışlarının Ölçülmesine Yönelik Bir Ölçek Geliştirme Çalışması". iktisadi ve idari Bilimler dergisi, vol. 29(4),pp. 659-678.

Dunlap, R. E., \& Van Liere, K. D. (1978). "The 'new environmental paradigm': a proposed measuring instrument and preliminary results". Journal of Environmental Education, vol. 9, pp. 10-19.

Dunlap, R. E., Van Liere, K. D., \& Mertig, A. G. (2000). “Measuring Endorsement Of The New Ecological Paradigm: A revised NEP scale". Journal of Social Issues, vol. 56, pp. 425-442.

Elgin, D. \& Mitchell, A. (1977). "Voluntary Simplicity". The Co-Evolution Quarterly, summer, pp. 5-18

Ellen, P.S., (1994) "Do we know what we need to know? Objective and subjective knowledge effects on pro-ecological behaviors". Journal of Business Research, vol. 30(1), pp.43-52.

Ellen, P. S., Wiener, J. L. \& Cobb-Walgren, C. (1991) "The Role of Perceived Consumer Effectiveness in Motivating Environmentally Conscious Behaviors". Journal of Public Policy and Marketing, vol. 10(2), pp.102-117.

Etzioni, A. (1998). "Voluntary Simplicity: Characterization, Select Psychological Implications, and Societal Consequences". Journal of Economic Psychology, vol. 19, pp. 619-643.

Faiers, A., \& Neame, C. (2006). “Consumer Attitudes Towards Domestic Solar Power Systems”. Energy Policy, vol. 34(14), pp. 1797-1806.

Festinger, L. (1957), A Theory of Cognitive Dissonance, Evanston, Peterson.

Frumkin, H., Hess, J., Luber, G., Malilay, J., \& McGeehin, M. (2008). “Climate Change: The Public Health Response”. American Journal of Public Health, vol. 98(3),pp. 435-445.

Fujii, S. (2006). “Environmental Concern, Attitude Toward Frugality, and Ease Of Behavior as Determinants of Pro-Environmental Behavior Intentions". Journal of Environmental Psychology, vol. 26(4),pp. 262-268.

Gadenne, D., Sharma, B., Kerr, D., \& Smith, T. (2011). “The Influence of Consumers' Environmental Beliefs and Attitudes On Energy Saving Behaviors". Energy Policy, vol. 39(12),pp. 7684-7694.

Gardner, G. T., \& Stern, P. C. (2008). "The Short List: The Most Effective Actions US Households Can Take to Curb Climate Change". Environment: Science and Policy for Sustainable Development, vol. 50(5),pp. 12-25.

Gifford, R. (2014). “Environmental Psychology Matters”. Psychology, vol. 65(1), pp.541-579.

Gifford, R., \& Nilsson, A. (2014). "Personal and Social Factors That Influence Pro-Environmental Concern And Behavior: A review". International Journal of Psychology, vol. 49(3),pp. 141-157.

Gilg, A., Barr, S., \& Ford, N. (2005). "Green Consumption or Sustainable Lifestyles? Identifying The Sustainable Consumer". Futures, vol. 37(6), pp. 481-504.

Gleim, M. R., Smith, J. S., Andrews, D., \& Cronin, J. J. (2013). “Against The Green: A Multi-Method Examination of The Barriers To Green Consumption". Journal of Retailing, vol. 89(1),pp. 44-61.

Goodwin, N., Nelson, J. A., Ackerman, F., \& Weisskopf T. (2008). Economic Activity In Context Microeconomics In Context, 1st Edition (Study Guide 2008).

Granzin, K. L., \& Olsen, J. E. (1991). “Characterizing Participants in Activities Protecting the Environment: A Focus on Donating, Recycling, and Conservation Behaviors". Journal of Public Policy and Marketing, pp.1-27.

Griskevicius, V., Ackerman, J. M., Tybur, J. M., Delton, A. W., Robertson, T. E., \& White, A. E. (2012). "The Financial Consequences Of Too Many Men: Sex Ratio Effects on Saving, Borrowing, and Spending". Journal of Personality and Social Psychology, vol. 102(1),pp. 69-80.

Griskevicius, V., Cantu, S., \& van Vugt, M. (2012). "The Evolutionary Bases for Sustainable Behavior: Implications for Marketing, Policy, and Social Entrepreneurship". Journal of Public Policy and Marketing, vol. 31(1), pp. 115-128.

Hartmann, P., \& Apaolaza-Ibáñez, V. (2008). "Virtual Nature Experiences As Emotional Benefits In Green Product Consumption The Moderating Role Of Environmental Attitudes". Environment and Behavior, vol. 40(6), pp.818-842.

Hartmann P., \& Apaolaza-Ibáñez V. (2012) "Consumer Attitude And Purchase Intention Toward Green Energy Brands: The Roles Of Psychological Benefits and Environmental Concern", Journal of Business Research, vol. 65, pp. 1254-1263. 
He, A. Z., Cai, T., Deng, T. X., \& Li, X. (2015). “Factors Affecting Non-Green Consumer Behaviour: An Exploratory Study Among Chinese Consumers". International Journal of Consumer Studies, vol. 40(3), pp. 345-356.

Henion, K. E. (1972). "The Effect Of Ecologically Relevant Information On Detergent Sales". Journal of Marketing Research, vol. 9 (1), pp. 10-14.

Heslop, L. A., Moran, L., \& Cousineau, A. (1981). "Consciousness" in Energy Conservation Behavior: An Exploratory Study. Journal Of Consumer Research, vol. 8(3), pp.299-305.

Hines, J. M., Hungerford, H. R., \& Tomera, A. N. (1987). "Analysis and Synthesis Of Research On Responsible Environmental Behavior: A meta-analysis". The Journal of Environmental Education, vol. 18(2), pp.1-8.

Hori, S., Kondo, K., Nogata, D., \& Ben, H. (2013). "The Determinants of Household Energy-Saving Behavior: Survey and Comparison In Five Major Asian Cities". Energy Policy, vol. 52, pp.354-362.

Huang, W., Wang, J., Dai, X., Li, M., \& Harder, M. K. (2014). “More Than Financial Investment Is Needed: Food Waste Recycling Pilots In Shanghai, China". Journal of Cleaner Production, vol. 67, pp.107-116.

Huneke, M. E. (2005). "The Face Of The Un-Consumer: An Empirical Examination Of The Practice Of Voluntary Simplicity in the United States". Psychology and Marketing, vol. 22(7), pp.527-550.

Irianto, H. (2015). "Consumers' Attitude and Intention towards Organic Food Purchase: An Extension of Theory of Planned Behavior in Gender Perspective". International Journal of Management, Economics and Social Sciences, vol. 4(1), pp.17-31.

Ishaswini and Datta, S. K. (2011). "Pro-environmental Concern influencing Green Buying: A study on Indian Consumers". International Journal of Business and Management, vol. 6(6),pp. 124-133.

Iwata, O, (1999). "Perceptual and Behavioral Correlates Of Voluntary Simplicity Lifestyles". Social Behavior and Personality: an international Journal, vol. 27,pp. 379-386.

Iwata, O, (2001). "Attitudinal Determinants of Environmentally Responsible Behavior". Social Behavior and Personality: An International Journal, vol. 29, pp.183-190,

Iyer, R., \& Muncy, J. A. (2009). “Purpose and Object Of Anti-Consumption”. Journal of Business Research, vol. 62(2), pp.160-168.

Jayanti, R. K., \& Burns, A. C. (1998). "The Antecedents of Preventive Health Care Behavior: An Empirical Study". Journal of the Academy of Marketing Science, vol. 26(1),pp.6-15.

Johnstone, M. L., \& Tan, L. P. (2015). "Exploring the Gap Between Consumers' Green Rhetoric And Purchasing Behaviour". Journal of Business Ethics, vol. 132(2),pp. 311-328.

Joshi, Y., \& Rahman, Z. (2015). "Factors Affecting Green Purchase Behaviour and Future Research Directions". International Strategic Management Review, vol. 3(1), pp.128-143.

Kalafatis, P. S., Pollard, M., East, R., \& Tsogas, H. M. (1999). “Green Marketing And Ajzen's Theory Of Planned Behavior: A Cross-Market Examination". Journal of Consumer Marketing, vol. 16, pp.441-460.

Karlin, B., Davis, N., Sanguinetti, A., Gamble, K., Kirkby, D., \& Stokols, D. (2014). "Dimensions of Conservation Exploring Differences Among Energy Behaviors". Environment and Behavior, vol. 46(4),pp. 423-452.

Kassarjian, H. H. (1971) “Incorporating Ecology into Marketing Strategy: The Case of Air Pollution”, Journal of Marketing, vol. 35, pp.61-65.

Kaufmann; H.R., Khan Panni, Mohammad Fateh Ali; \& Orphanidou, Yianna (2012), “Factors Affecting Consumers' Green Purchasing Behavior: An Integrated Conceptual Framework", The Amfiteatru Economic Journal, vol. 14, (31), pp.50-69.

Kilbourne, W., \& Pickett, G. (2008). "How Materialism Affects Environmental Beliefs, Concern, And Environmentally Responsible Behavior". Journal of Business Research, vol. 61(9), pp.885-893.

Kim, Y., \& Choi, S. M. (2005). "Antecedents of Green Purchase Behavior: An Examination Of Collectivism, Environmental Concern, And PCE”. Advances in Consumer Research, vol. 32, pp. 592-599.

Kinnear, T. C., \& Taylor, J. R. (1973). "The Effect of Ecological Concern On Brand Perceptions". Journal of Marketing Research, pp. $191-197$.

Kinnear T.C., Taylor J.R., \& Ahmed S.A. (1974). “Ecologically Concerned Consumers: Who Are They?” Journal of Marketing; vol. 38(2),pp.2024.

Koenig-Lewis, N., Palmer, A., Dermody, J., \& Urbye, A. (2014). “Consumers' Evaluations Of Ecological Packaging-Rational And Emotional Approaches". Journal of Environmental Psychology, vol. 37,pp. 94-105.

Kriwy, P., \& Mecking, R. A. (2012). "Health and Environmental Consciousness, Costs of Behavior And The Purchase Of Organic Food". International Journal of Consumer Studies, vol. 36(1), pp. 30-37.

Largo-Wight, E., Bian, H., \& Lange, L. (2012). “An Empirical Test of an Expanded Version of the Theory of Planned Behavior in Predicting Recycling Behavior On Campus". American Journal of Health Education, vol. 43(2), pp.66-73. 
Laroche, M., Bergeron, J., \& Barbaro-Forleo, G. (2001). “Targeting Consumers Who Are Willing To Pay More For Environmentally Friendly Products". Journal of Consumer Marketing, vol. 18(6), pp.503-520.

Lastovicka, J. L., Bettencourt, L. A., Hughner, R. S., \& Kuntze, R. J. (1999). "Lifestyle of the Tight and Frugal: Theory And Measurement". Journal of Consumer Research, vol. 26(1),pp. 85-98.

Lee Y., Kim S., Kim M., \& Choi J. (2014). "Antecedents and Interrelationships Of Three Types Of Pro-Environmental Behavior". Journal of Business Research, vol. 67(10) , pp. 2097-2105.

Leonard-Barton, D. (1981). "Voluntary Simplicity Lifestyles And Energy Conservation”. Journal of Consumer Research, vol. 8, pp. 243-252.

Lindsay, J. J., \& Strathman, A. (1997). Predictors of Recycling Behavior: An Application of a Modified Health Belief Model". Journal of Applied Social Psychology, vol. 27(20),pp. 1799-1823.

Magnusson, M. K., Arvola, A., Hursti, U. K. K., Åberg, L., \& Sjödén, P. O. (2003). “Choice of organic Foods Is Related to Perceived Consequences for Human Health and to Environmentally Friendly Behaviour”. Appetite, vol. 40(2), pp.109-117.

Mainieri, Tina; Barnett, Elaine G.; Valdero, Trisha; Unipan, John B.; \& Oskamp, Stuart (1997). "Green buying: The Influence Of Environmental Concern On Consumer Behavior". The Journal of Social Psychology, vol. 137(2):189-204.

Maloney, M. P.;\& Ward, M. P. (1973) “Ecology: Let's Hear From the People, An Objective Scale for the Measurement of Ecological Attitudes and Knowledge", American Psychologist, vol. 28(7), pp.583-586.

McCarty, J. A., \& Shrum, L. J. (1994). "The recycling of Solid Wastes: Personal Values, Value Orientations, and Attitudes about Recycling as Antecedents of Recycling Behavior". Journal of Business Research, vol. 30(1), pp. 53-62.

McCarty, J. A., \& Shrum, L. J. (2001). "The Influence Of Individualism, Collectivism, And Locus Of Control On Environmental Beliefs And Behavior". Journal of Public Policy and Marketing, vol. 20(1), pp. 93-104.

McDonald, S., Oates, C. J., Young, C. W., \& Hwang, K. (2006). "Toward Sustainable Consumption: Researching Voluntary Simplifiers". Psychology \& Marketing, vol. 23(6), pp. 515-534.

Meadows, D. H., Meadows, D. L., Randers, J., \& Behrens, W. W. (1972) The Limits to Growth. New York: Universe Books.

Menon, A., \& Menon, A. (1997). "Enviropreneurial Marketing Strategy: The Emergence Of Corporate Environmentalism As Market Strategy". Journal of Marketing, vol. 61 (1), pp. 51-67.

Michaelidou, N., \& Hassan, L.M. (2008). “The Role Of Health Consciousness, Food Safety Concern And Ethical Identity On Attitudes And Intentions Towards Organic Food". International Journal of Consumer Studies, vol. 32(2), pp. 163-170.

Minton, A. P. \& Rose, R. L. (1997). "The effects of Environmental Concern on Environmentally Friendly Consumer Behavior: An Exploratory Study". Journal of Business Research, vol. 40(1), pp.37-48.

Nepomuceno, M. V., \& Laroche, M. (2015). “The Impact of Materialism And Anti-Consumption Lifestyles On Personal Debt And Account Balances". Journal of Business Research, vol. 68(3),pp. 654-664.

Niemeyer, S. (2010). “Consumer Voices: Adoption Of Residential Energy-Efficient Practices”. International Journal of Consumer Studies, vol. $34(2)$, pp.140-145.

Nunnally, J.C., 1978. Psychometric Theory, 2nd ed. McGraw-Hill, New York, NY.

Oikonomou, V., Becchis, F., Steg, L., and Russolillo, D. (2009). “Energy Saving And Energy Efficiency Concepts For Policy Making”. Energy policy, vol. 37(11), pp. 4787-4796.

Olsen, M. E. (1981). “Consumers' Attitudes Toward Energy Conservation”. Journal of Social Issues, vol. 37(2),pp. 108-131.

Ozanne, L. K., \& Ballantine, P. W. (2010). "Sharing as a Form of Anti-Consumption? An Examination of Toy Library Users". Journal of Consumer Behaviour, vol. 9(6), pp. 485-498.

Ozanne, L. K., \& Ozanne, J. L. (2009, July). Parental Mediation Of The Market's Influence On Their Children: Toy Libraries As Safe Havens. In Leeds, UK: Academy of Marketing Annual Conference (pp. 7-9).

Paço, A. D., \& Varejão, L. (2010). “Factors affecting Energy Saving Behavior: A Prospective Research”. Journal of Environmental Planning And Management, vol. 53(8),pp. 963-976.

Pagiaslis, Anastasios P. \& Athanasios, Krystallis, (2014) “Green Consumption Behavior Antecedents: Environmental Concern, Knowledge, and Beliefs". Psychology \& Marketing, vol. 31(5), pp. 335-348.

Painter, J., R. Semenik and R. Belk (1983), Is there a generalized conservation ethic? A comparison of the Determinants of Gasoline and Home Heating Energy Conservation, Journal of Economic Psychology, vol. 3,pp. 317-331.

Passyn, K., and Sujan, M. (2006). Self-accountability Emotions And Fear Appeals: Motivating Behavior. Journal of Consumer Research, 32(4), pp.583-589.

Peattie,K.,(2010) “Green Consumption: Behavior and Norms”. Annual Review of Environment and Resources, vol. 35, pp. 195-228. 
Pedersen, L. H. (2000). “The Dynamics of Green Consumption: A Matter of Visibility?" Journal of Environmental Policy and Planning, vol. 2(3),pp.193-210.

Pepper, M., Jackson, T., \& Uzzell, D. (2009). “An Examination Of The Values That Motivate Socially Conscious and Frugal Consumer Behaviors". International Journal of Consumer Studies, vol. 33(2), pp.126-136.

Pinto,Costa D., Herter, M. M., Rossi, P., \& Borges, A. (2014). “Going Green For Self Or For Others? Gender And Identity Salience Effects On Sustainable Consumption". International Journal of Consumer Studies, vol. 38(5),pp. 540-549.

Poortinga, W., Steg, L., \& Vlek, C. (2004). "Values, Environmental Concern, And Environmental Behavior a Study into Household Energy use". Environment and Behavior, vol. 36(1), pp. 70-93.

Qader, I. A., \& Zainuddin , Y. (2010). “Intention to Purchase Green Electronic Products: The Consequences of Perceived Government Legislation, Media Exposure and Safety and Health Concern and the Role of Attitude as Moderator". International Journal of Innovation, Management and Technology, vol. 1(4),pp. 432-440.

Raaij, W. Fred Van \& Verhallen, Theo M.M.(1983). “A Behavioral Model of Residential Energy Use”. Journal of Economic Psychology, vol. v 3(1), pp.39-63.

Richins, M. L., \& Dawson, S. (1992). “A Consumer Values Orientation for Materialism and Its Measurement: Scale Development and Validation". Journal of Consumer Research, vol. 19(3),pp.303-316.

Rick, S. I., Cryder, C. E., \& Loewenstein, G. (2008). “Tightwads and Spendthrifts”. Journal of Consumer Research, 34(6), pp.767-782.

Ritter, Agata M. Borchardt,M., Vaccaro, Guilherme L.R., Pereira, Giancarlo M., \& Almeida, F. (2015) "Motivations for Promoting The Consumption Of Green Products In An Emerging Country: Exploring Attitudes Of Brazilian Consumers". Journal of Cleaner Production, vol. 106,pp. 507-520.

Roberts, J. A. (1995). "Profiling Levels Of Socially Responsible Consumer Behavior: A Cluster Analytic Approach And Its Implications For Marketing". Journal of Marketing Theory and Practice. vol. 3 (4), pp. 97-117.

Roberts, J. A. (1996). "Green Consumers in the 1990s: Profile and Implications for Advertising". Journal of Business Research, vol. 36(3), pp.217-231.

Roberts, J. A., \& Bacon, D. R. (1997). “Exploring the Subtle Relationships Between Environmental Concern And Ecologically Conscious Consumer Behavior". Journal of Business Research, vol. 40(1), pp. 79-89.

Rundmo, T. (1999). “Perceived Risk, Health and Consumer Behavior”. Journal of Risk Research, vol. 2(3),pp. 187-200.

Sanne, C. (2002). “Willing consumers-or locked-in? Policies For A Sustainable Consumption”. Ecological Economics, vol. 42(1), pp.273-287.

Schreinemachers, D. M., \& Ghio, A. J. (2016). "Effects of Environmental Pollutants on Cellular Iron Homeostasis and Ultimate Links to Human Disease". Environmental health insights, vol. 10, 35.

Schultz, P. W., Gouveia, V. V., Cameron, L. D., Tankha, G., Schmuck, P., \& Franěk, M. (2005). Values and their relationship to environmental concern and conservation behavior. Journal of cross-cultural psychology, 36(4),pp. 457-475.

Schultz, P. W., Oskamp, S., \& Mainieri, T. (1995). "Who recycles and when? A Review Of Personal And Situational Factors". Journal of Environmental Psychology, 15(2), pp.105-121.

Schultz, P. W., \& Zelezny, L. C. (1998). "Values and Proenvironmental Behavior A Five-Country Survey". Journal of Cross-Cultural Psychology, vol. 29(4), pp.540-558.

Schultz, P. W., \& Zelezny, L. (1999). "Values as Predictors of Environmental Attitudes: Evidence for Consistency Across 14 Countries". Journal of Environmental Psychology, vol. 19(3), pp.255-265.

Seegebarth, B., Peyer, M., Balderjahn, I., \& Wiedmann, K. (2015). "The Sustainability Roots of Anticonsumption Lifestyles and Initial Insights Regarding Their Effects on Consumers' Well-Being". Journal Of Consumer Affairs, vol. 50(1), pp.68-99.

Seligman, C., Kriss, M., Darley, J. M., Fazio, R. H., Becker, L. J., \& Pryor, J. B. (1979). “Predicting Summer Energy Consumption from Homeowners' Attitudes". Journal of Applied Social Psychology, vol. 9(1), pp. 70-90.

Shaw, D., \& Moraes, C. (2009). "Voluntary Simplicity: An Exploration of Market Interactions". International Journal of Consumer Studies, vol. 33(2), pp.215-223

Shaw, D., \& Newholm, T. (2002). “Voluntary Simplicity and the Ethics of Consumption”. Psychology \& Marketing, vol. 19(2),pp. $167-185$.

Sheth, J. N., Sethia, N. K., \& Srinivas, S. (2011). "Mindful Consumption: A Customer-Centric Approach To Sustainability". Journal of the Academy of Marketing Science, vol. 39(1),pp. 21-39.

Shoham, A., \& Brenčič, M. M. (2004). "Value, Price Consciousness, and Consumption Frugality: An Empirical Study". Journal of International Consumer Marketing, vol. 17(1), pp.55-69.

Shrum, L J; McCarty, J. A; \& Lowrey, T.M., (1995). "Buyer Characteristics Of The Green Consumer And Their Implications For Advertising Strategy", Journal of Advertising, vol. 24(2), pp.7-82. 
Steg, L. (2008). “Promoting Household Energy Conservation”. Energy Policy, vol. 36(12), pp.4449-4453.

Steg, L., Dreijerink, L., \& Abrahamse, W. (2005). "Factors Influencing the Acceptability of Energy Policies: A Test Of VBN Theory". Journal of Environmental Psychology, vol. 25(4),pp. 415-425.

Steg, L., \& C. Vlek. (2009). "Encouraging Pro-environmental Behavior: An Integrate Review and Research". Journal of Environmental Psychology, vol. 29 (3), pp.309-317.

Stern, P. C. (1992). “What psychology knows about energy conservation?” American Psychologist, vol. 47(10),pp. 1224-1232.

Stern, P. C. (2000) "Toward a Coherent Theory of Environmentally Significant Behavior", Journal of Social Issues, vol. 56(3),pp. 407-424.

Stern, P. C., Dietz, T., \& Kalof, L. (1993). “Value Orientations, Gender, and Environmental Concern”. Environment and Behavior, vol. 25(5), pp. 322-348.

Stern, P. C., \& Dietz, T. (1994). “The Value Basis of Environmental Concern”. Journal of social issues, vol. 50(3),pp. 65-84.

Straughan, R. D., \& Roberts, J. A. (1999). “Environmental Segmentation Alternatives: A Look At Green Consumer Behavior In The New Millennium". Journal of Consumer Marketing, vol. 16(6),pp. 558-575.

Sütterlin, B., Brunner, T. A., \& Siegrist, M. (2011). "Who puts the most energy into energy conservation? A Segmentation of Energy Consumers Based On Energy-Related Behavioral Characteristics". Energy Policy, vol. 39(12),pp.8137-8152.

Testa, F., Cosic, A., \& Iraldo, F. (2016). “Determining Factors Of Curtailment and Purchasing Energy Related Behaviors". Journal of Cleaner Production, 112, pp. 3810-3819.

Thøgersen, J., \& Noblet, C. (2012). "Does Green Consumerism Increase The Acceptance Of Wind Power"?. Energy Policy, vol. 51,pp. 854862 .

Thogersen,J., \& Olander, F., (2002). "Human Values and the Emergence of a Sustainable Consumption Pattern: A Panel Study", Journal of Economic Psychology, vol. 23(5), pp.605-630.

Thøgersen, J., \& Ölander, F. (2006). "To what degree are environmentally beneficial choices reflective of a general conservation stance?". Environment and Behavior, vol. 38(4), pp. 550-569.

Thøgersen, J. (2014). “Unsustainable Consumption: Basic Causes and Implications for Policy”. European Psychologist. vol. 19 (2), pp. $84-95$

Ture, R. S., \& Ganesh, M. P. (2012). "Effect of Health Consciousness and Material Values On Environmental Belief And Pro-Environmental Behaviors". International Proceedings of Economics Development and Research, vol. 43,pp. 41-45.

Ulusoy, E. (2016). “Experiential Responsible Consumption”. Journal of Business Research, vol. 69(1), pp.284-297.

Van Liere K.D.; \& Dunlap, R. E. (1980) “The Social Bases of Environmental Concern: A Review of Hypotheses, Explanations and Empirical Evidence", Public Opinion Quarterly, vol. 44(2), pp.181-197.

Verhallen, T. M., \& Van Raaij, W. F. (1981). "Household Behavior and the Use of Natural Gas for Home Heating”. Journal Of Consumer Research, vol. 8(3), pp. 253-257.

Vermeir, I., \& Verbeke, W. (2008). "Sustainable Food Consumption Among Young Adults In Belgium: Theory of Planned Behavior and The Role of Confidence and Values". Ecological Economics, vol. 64(3),pp. 542-553.

Vivian, S., Haslam, K., Soldner, M. \& Sangster, M. (2011), “Assessment of European Energy and Carbon Profiles Of Manual and Automatic Dishwashing". International Journal of Consumer Studies, vol. 35, pp.187-193.

Weigel, R., \& Weigel, J. (1978). “Environmental Concern the Development of A Measure”. Environment and Behavior, vol. 10(1), pp. 3-15.

Witkowski, T. H. (2010). "A Brief History of Frugality Discourses in The United States”. Consumption, Markets and Culture, vol. 13(3),pp. 235-258.

Yavetz, B.; Goldman, D.; Pe'er, S. (2009) “Environmental Literacy Of Pre-Service Teachers In Israel: A Comparison Between Students at The Onset and End of Their Studies". Environmental Education Research, vol. 15(4), pp. 399-416.

Young, W., Hwang, K., McDonald, S., \& Oates, C. J. (2010). "Sustainable Consumption: Green Consumer Behaviour When Purchasing Products". Sustainable Development, vol. 18(1), pp. 20-31.

Yue, T., Long, R., \& Chen, H. (2013). "Factors Influencing Energy-Saving Behavior of Urban Households in Jiangsu Province”. Energy Policy, vol. 62, pp. 665-675.

Zhao, H. H., Gao, Q., Wu, Y. P., Wang, Y., \& Zhu, X. D. (2014). "What Affects Green Consumer Behavior in China? A Case Study from Qingdao". Journal of Cleaner Production, vol. 63, pp. 143-151.

Zimmer, M. R., Stafford, T. F., \& Stafford, M. R. (1994). “Green Issues: Dimensions of Environmental Concern”. Journal of Business Research, vol. 30(1), pp.63-74. 
